\section{Commentary: Surgical mitral-in-mitral annular calcification: Progress but not the solution}

\author{
J. James Edelman, MBBS(Hons), $\mathrm{PhD},{ }^{\mathrm{a}}$ \\ Pradeep K. Yadav, MD, ${ }^{b}$ and Vinod H. Thourani, MD $^{\mathrm{c}}$
}

Mitral annular calcification (MAC) in association with mitral valve pathology requiring surgery is a challenging problem. Resection of MAC is associated with the risk of atrioventricular disruption, whilst placing a prosthesis without MAC debridement is associated with small prosthesis size and paravalvular regurgitation. MAC is most often found in elderly patients with multiple medical comorbidities who are already at considerable risk of death if undergoing traditional cardiac surgery; therefore, many patients are not offered surgery. ${ }^{1}$

Several techniques to manage MAC have been described, broadly grouped into complete resection of the MAC with annular reconstruction, or incomplete (or no) resection. Feindel and colleagues ${ }^{2}$ and Carpentier and colleagues ${ }^{3}$ have described the classic techniques for complete en bloc resection of MAC with annular reconstruction. Other groups have described modifications of the classic techniques, including a recently published impressive series of 54 robotic MAC resections with mitral valve repair. ${ }^{4-6}$ Various techniques of incomplete resection have also been described. ${ }^{7-9}$ More

From the ${ }^{\mathrm{a} D e p a r t m e n t}$ of Cardiothoracic Surgery, Fiona Stanley Hospital, Perth, Western Australia, Australia; and ${ }^{\mathrm{b}}$ Division of Cardiology, and ${ }^{\mathrm{c}}$ Department of Cardiovascular Surgery, Marcus Valve Center, Piedmont Heart Institute, Atlanta, $\mathrm{Ga}$.

Disclosures: Dr Thourani has served as an advisor and assisted with research for Abbott Vascular and Edwards Lifesciences. Dr Yadav has served as a proctor and consultant for Edwards Lifesciences and as a consultant for Shockwave Medical. Dr Edelman reported no conflicts of interest.

The Journal policy requires editors and reviewers to disclose conflicts of interest and to decline handling or reviewing manuscripts for which they may have a conflict of interest. The editors and reviewers of this article have no conflicts of interest.

Received for publication March 6, 2020; revisions received March 6, 2020; accepted for publication March 8, 2020; available ahead of print April 1, 2020.

Address for reprints: Vinod H. Thourani, MD, Department of Cardiovascular Surgery, Piedmont Heart Institute, 95 Collier Rd, Suite 5015, Atlanta, GA 30308 (E-mail: vinod.thourani@piedmont.org).

JTCVS Techniques 2020;3:138-9

2666-2507

Copyright (C) 2020 The Authors. Published by Elsevier Inc. on behalf of The American Association for Thoracic Surgery. This is an open access article under the CC BY-NCND license (http://creativecommons.org/licenses/by-nc-nd/4.0/).

https://doi.org/10.1016/j.xjtc.2020.03.003

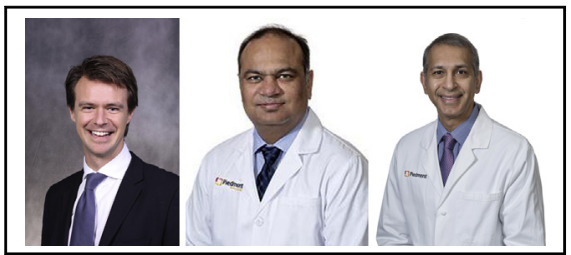

J. James Edelman, MBBS(Hons), PhD, Pradeep K. Yadav, MD, and Vinod H. Thourani, MD

CENTRAL MESSAGE

Mitral valve disease and severe

mitral annular calcification are difficult to treat. Hybrid solutions

using novel valves represent

progress until a percutaneous

solution can be refined.

recently, percutaneous transcatheter mitral valve replacement (TMVR) in MAC has been hampered by a relatively high rate of acute obstruction of the left ventricular outflow tract (LVOT), a near-lethal complication. ${ }^{10}$ In contrast, an open transatrial approach, where a transcatheter aortic valve (TAVR) prosthesis, generally with a balloon-expandable Sapien 3 valve (Edwards Lifesciences, Irvine, Calif), is placed under vision into the calcified mitral annulus has reported good results. ${ }^{11}$ The Tendyne valve (Abbott Vascular, Santa Clara, Calif) is a dedicated transcatheter mitral valve prosthesis placed in a beating heart from the apex and the Mitral in MAC feasibility trial is currently underway as a substudy within the Feasibility Study of the Tendyne Mitral Valve System for Use in Subjects With Mitral Annular Calcification (NCT03539458).

Vodstrup and colleagues ${ }^{12}$ describe the placement of a rapiddeployment Intuity valve (Edwards Lifesciences) into the calcified mitral annulus of a 72-year-old patient with severe MAC with mitral stenosis. Sutures were placed through leaflet tissue and the anterior leaflet left intact. The patient recovered well, with mild mitral stenosis and mild LVOT gradient, but experienced a minor stroke 4 months postoperatively.

The authors should be congratulated for a novel solution to a difficult problem; the case raises several important points. Rapid-deployment aortic valve prostheses have found a place in aortic valve replacement because surgeons can resect calcified leaflets (unlike in TAVR), whilst minimizing crossclamp time in high-risk patients. The advantage over a TAVR valve in open mitral-in-MAC procedures is less clear, other than potential cost saving on the valve itself. Russell and colleagues ${ }^{11}$ have described 
in detail their open transatrial technique, which includes resection of the anterior leaflet to reduce LVOT obstruction, placement of sutures through the annulus where possible, and a felt ring around the skirt to reduce paravalvular regurgitation. All but 2 patients had a $29-\mathrm{mm}$ prosthesis (those two had a $26-\mathrm{mm}$ prosthesis), considerably larger than the 23-mm Intuity prosthesis placed in the aforementioned case. Like Russell and colleagues, we consider resection of the anterior leaflet essential to reduce LVOT obstruction. When the anterior leaflet is removed, blood can flow through the open cells of a Sapien 3 transcatheter valve. However, the basal or atrial half of a Sapien 3 valve still has covered cells that may cause obstruction in very small LVOTs. This is difficult to assess intraoperatively in a nonbeating heart but could be predicted by calculating skirt neo-LVOT on a gated contrast enhanced computed tomography (CT). For such patients, additional steps like concomitant basal septal myectomy should be considered during transatrial TMVR. Unlike percutaneous TMVR, CT is not mandatory for the transatrial technique; however, CT offers tremendous preprocedural insight and could be considered part of routine preoperative workup.

The authors do not discuss whether or not the patient was receiving anticoagulation therapy during the postoperative period. The American Heart Association/American College of Cardiology guidelines recommend 3 to 6 months of anticoagulation therapy (classification IIa) after placement of a bioprosthetic valve in the aortic or mitral position, but this is supported by very little data. ${ }^{13}$ Improving our understanding of this issue should be a focus of the structural heart community.

Until a dedicated transcatheter solution to mitral valve disease in MAC can be identified, novel techniques to improve open surgical outcomes should be applauded and encouraged.

\section{References}

1. Tsutsui RS, Simsolo E, Saijo Y, Gentry J, Puri R, Reed G, et al. Severe mitral stenosis in patients with severe mitral annular calcification: an area of unmet need. JACC Cardiovasc Interv. 2019;12:2566-8.

2. Feindel CM, Tufail Z, David TE, Ivanov J, Armstrong S. Mitral valve surgery in patients with extensive calcification of the mitral annulus. J Thorac Cardiovasc Surg. 2003;126:777-82.

3. Carpentier AF, Pellerin M, Fuzellier JF, Relland JY. Extensive calcification of the mitral valve anulus: pathology and surgical management. J Thorac Cardiovasc Surg. 1996;111:718-29.

4. Uchimuro T, Fukui T, Shimizu A, Takanashi S. Mitral valve surgery in patients with severe mitral annular calcification. Ann Thorac Surg. 2016;101: 889-95.

5. Casselman FP, Gillinov AM, McDonald ML, Cosgrove DM. Use of the anterior mitral leaflet to reinforce the posterior mitral annulus after debridement of calcium. Ann Thorac Surg. 1999;68:261-2.

6. Loulmet DF, Ranganath NK, Neragi-Miandoab S, Koeckert MS, Galloway AC, Grossi EA. Advanced experience allows robotic mitral valve repair in the presence of extensive mitral annular calcification. J Thorac Cardiovasc Surg. November 2, 2019 [Epub ahead of print].

7. Nataf P, Pavie A, Jault F, Bors V, Cabrol C, Gandjbakhch I. Intraatrial insertion of a mitral prosthesis in a destroyed or calcified mitral annulus. Ann Thorac Surg. 1994:58:163-7.

8. Di Stefano S, López J, Flórez S, Rey J, Arevalo A, San Román A. Building a new annulus: a technique for mitral valve replacement in heavily calcified annulus Ann Thorac Surg. 2009;87:1625-7.

9. Hussain ST, Idrees J, Brozzi NA, Blackstone EH, Pettersson GB. Use of annulus washer after debridement: a new mitral valve replacement technique for patients with severe mitral annular calcification. J Thorac Cardiovasc Surg. 2013;145: $1672-4$.

10. Guerrero M, Urena M, Himbert D, Wang DD, Eleid M, Kodali S, et al. 1-Year outcomes of transcatheter mitral valve replacement in patients with severe mitral annular calcification. J Am Coll Cardiol. 2018;71:1841-53.

11. Russell HM, Guerrero ME, Salinger MH, Manzuk MA, Pursnani AK Nemeh $\mathrm{H}$, et al. Open atrial transcatheter mitral valve replacement in patients with mitral annular calcification. J Thorac Cardiovasc Surg. 2018; 72:1437-48.

12. Vodstrup HJ, Terp K. A case of open atrial implantation of a rapid deploymen valve in a patient with severe mitral annular calcification. J Thorac Cardiovasc Surg Tech. 2020;3:133-5.

13. Nishimura RA, Otto CM, Bonow RO, Carabello BA, Erwin JP, Fleisher LA, et al 2017 AHA/ACC focused update of the 2014 AHA/ACC guideline for the management of patients with valvular heart disease: a report of the American College of Cardiology/American Heart Association task force on clinical practice guidelines. Circulation. 2017;135:e1159-95. 